\title{
AID-induced remodeling of immunoglobulin genes and B cell fate
}

\author{
Brice Laffleur $^{1,2}$, Nicolas Denis-Lagache ${ }^{1,2}$, Sophie Péron ${ }^{1,2}$, Christophe Sirac ${ }^{1,2}$, \\ Jeanne Moreau ${ }^{1,2}$ and Michel Cogné ${ }^{1,2,3}$ \\ ${ }^{1}$ Limoges University, Limoges France ; \\ ${ }^{2}$ Centre National de la Recherche Scientifique, \\ ${ }^{3}$ Institut Universitaire de France, Limoges, France \\ Correspondence to: Michel Cogné, email:cogne@unilim.fr
}

Keywords: AID; B cell fate; BCR, immunoglobulin genes

Received: October 28, $2013 \quad$ Accepted: December 12, $2013 \quad$ Published: December 14, 2013

This is an open-access article distributed under the terms of the Creative Commons Attribution License, which permits unrestricted use, distribution, and reproduction in any medium, provided the original author and source are credited.

\section{ABSTRACT:}

Survival and phenotype of normal and malignant B lymphocytes are critically dependent on constitutive signals by the $B$ cell receptor (BCR) for antigen. In addition, either antigen ligation of the BCR or various mitogenic stimuli result in B cell activation and induction of activation-induced deaminase (AID). AID activity can in turn mediate somatic hypermutation (SHM) of immunoglobulin ( $\mathrm{Ig}$ ) $\mathrm{V}$ regions and also deeply remodel the Ig heavy chain locus through class switch recombination (CSR) or locus suicide recombination (LSR). In addition to changes linked to affinity for antigen, modifying the class/isotype (i.e. the structure and function) of the BCR or suddenly deleting BCR expression also modulates the fate of antigen-experienced $B$ cells.

\section{AID FUNCTION AND SITES OF ACTION}

Activation-induced deaminase (AID), an ancestral AID/APOBEC family member, deaminates DNA cytidines into uridines within immunoglobulin $(\mathrm{Ig})$ variable $(\mathrm{V})$ regions in all vertebrate species carrying $\mathrm{B}$ cells, thus supporting their Ag-driven diversification through gene conversion (GCV) and/or somatic hypermutation (SHM) [1]. It also diversifies expression of Ig heavy chain $(\operatorname{IgH})$ constant $(\mathrm{CH})$ regions in frogs, birds and mammals, who have developed class switch recombination (CSR) of $\mathrm{CH}$ genes.

AID was first identified as specifically expressed during the antigen-driven $\mathrm{B}$ cell maturation that mostly occurs in germinal centers (GC) of peripheral lymphoid organs [2]. It is mandatory for SHM and CSR [3] while its defect in patients results in hyper-IgM immune deficiency [4]. Its random mutagenic activity alters $\mathrm{V}$ domain complementarity determining regions, and thus modulates BCR (and later on antibody) binding affinity in a selection process where SHM is coordinated with cell competition for optimal intra-GC interactions with antigen-presenting cells [5]. In some mammals, especially in cattle, AIDmediated SHM can also begin in fetal gut associated lymphoid tissues prior to any contact with exogenous antigens [6].

Biochemically, G:U mismatches created through AID deamination can be processed in several ways, preferentially leading to mutations rather than repair within Ig genes. In « phase $1 »$ mutations, direct replication across a $\mathrm{G}: \mathrm{U}$ mismatch can generate transitions from $\mathrm{G}: \mathrm{C}$ to A:T base pairs. Base excision repair (BER) and uracil removal by uracil N-glycosylase (UNG) instead generate abasic sites, which subsequently undergo DNA nicking by apurinic/apyrimidinic endonuclease, and are repaired during replication by error-prone DNA polymerases as both transitions and transversions. G:U mismatches can also be processed by the mismatch repair (MMR) pathway involving MSH2/MSH6, with associated error-prone DNA polymerases and then result in patches of " phase 2 » mutations at both G:C and (preferentially) A:T base pairs around targeted cytosines.

Primary regulation of AID activity in B cells relies on its strictly controlled tissue-specific and stage-specific expression upon cell activation, due to control of the level of AID transcripts by both ubiquitous and lymphoidspecific transcription factors (Pax-5, STAT6, SP1, C/EBP) and miRNAs (miR155 and miR181b). This ensures high AID expression only in activated B cells with appropriate signals, as occurring within GCs upon interaction with 
follicular dendritic cells and $\mathrm{T}$ follicular helper cells. In addition, AID can appear at low levels in some bone marrow developing $B$ cells upon stimulation of toll like receptors (TLR) $[7,8]$.

AID requires transcription of target regions and also preferentially deaminates cytosine into uracil within WRC motifs ( $\mathrm{W}=\mathrm{A} / \mathrm{T}, \mathrm{R}=\mathrm{A} / \mathrm{G})$ [9]. Besides potential constraints concerning the "accessibility" of target DNA, another major link between AID targeting and transcription is that AID loading onto Ig genes requires physical interaction with stalled RNAPII and bound Spt5 that occurs immediately downstream from transcription start sites [10]. The RNAPII associated polymerase associated factor (PAF) complex also helps recruit AID [11]. $\mathrm{CH}$ regions are protected from AID attack due to the absence of RNAPII pausing. Switch (S)-region transcription before AID recruitment is under the control of cytokine-dependent germline promoters preceding $\mathrm{CH}$ regions and a series of $\mathrm{B}$ cell activationdependent transcriptional enhancers located in the 3' regulatory region ( $\left.3^{\prime} \mathrm{RR}\right)$ of the $\mathrm{IgH}$ locus [12-15]. While AID generates mutations in $\mathrm{V}$ regions, it initiates DNA breaks (DSBs) in S regions, thereby promoting large deletions $[16,17]$. DSBs activate the ubiquitous DNA damage response, which is then resolved through classical (C-) or alternative non-homologous end joining
(A-NHEJ). Recruitment of 53BP1 and Rif1 [18] to broken DNA ends (and subsequent formation of $\gamma \mathrm{H} 2 \mathrm{AX}$ foci) is required for protection of DNA ends from resection before repair and ligation by C-NHEJ rather than A-NHEJ [19, 20]. AID recruitment to both $\mathrm{V}$ and $\mathrm{S}$ regions (and S-S region synapses, likely favored by IgH locus DNA loops) requires $\mathrm{IgH} 3$ ' RR enhancer activity elements [13] [15] [14] [21] [22]. Multiple 3'RR genetic alterations affected transcription of AID targeted regions [12-15]. However, transcription was often partially reduced while being associated with complete CSR and/or SHM blockades. In addition to boosting transcription, the 3'RR thus likely promotes AID activity through epigenetic changes of targets, or by attracting and recruiting AID and/or AID partners. Figure 1 resumes the different targets of AID in the IgH locus.

\section{CSR AND BCR CLASS-SPECIFIC CONTROL OF B CELL FATE}

\subsection{Structure and function of the B Cell Receptor}

The B cell receptor is composed of a membranebound immunoglobulin (mIg) associated with the

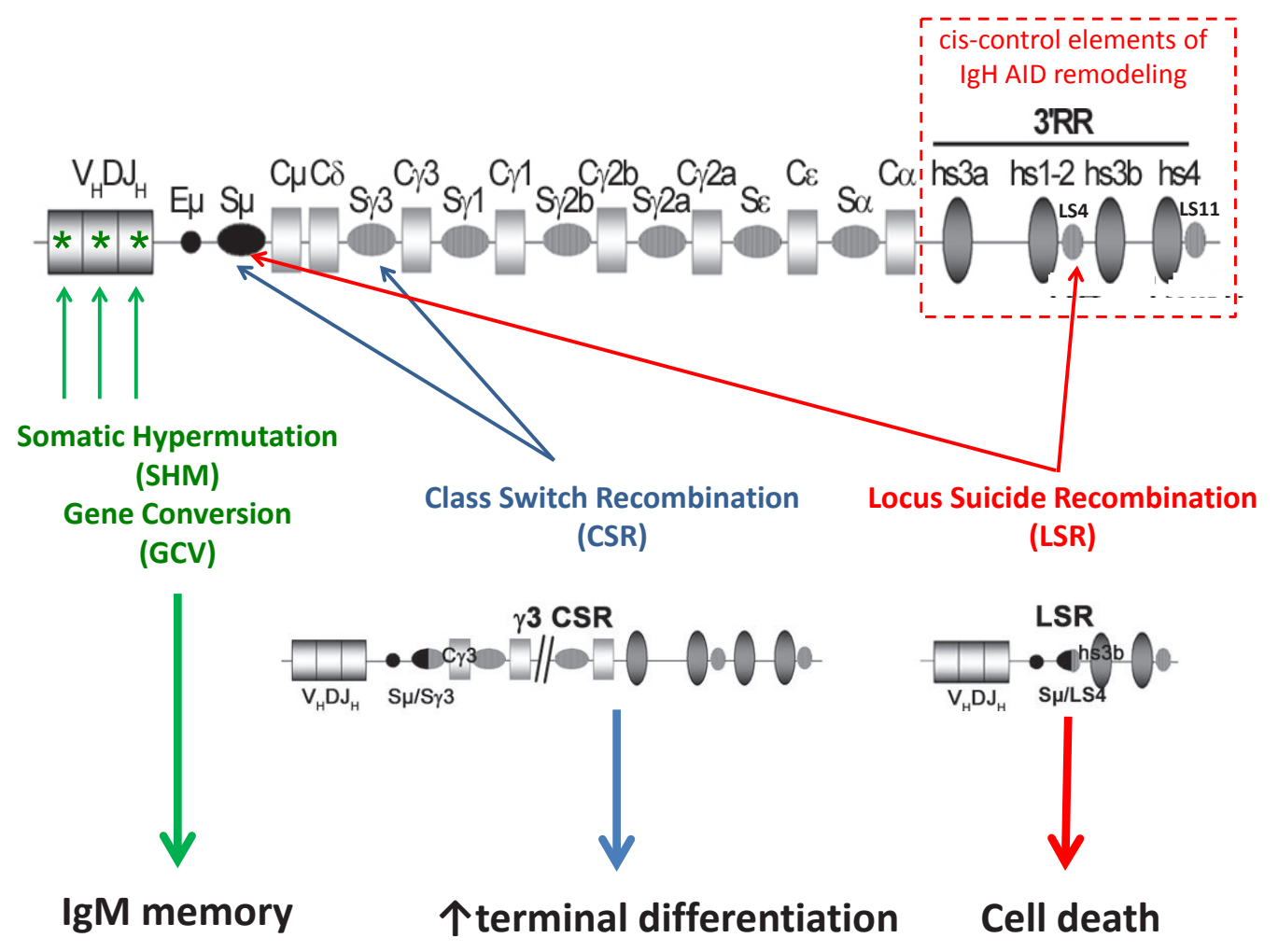

Figure 1: AID targeting of the IgH locus. Upon B cell activation, induced AID expression remodels Ig gene V regions through SHM or eventually gene conversion (GCV), generating B cell receptors of improved affinity for antigen. B cells, in parallel or later, diversify the BCR class through class switch recombination (CSR). Locus suicide recombination (LSR) eventually joins the switch $\mu$ region (S $\mu$ ) with one of the like-switch (LS) repetitive regions located within the 3' regulatory region (3'RR), then deletes all IgH constant genes and switches off BCR expression, thus leading to B cell death. 
disulfide-linked heterodimer transducing module CD79A / CD79B (Iga / Igß). The mIg is composed of two heavy (H) and two light (L) chains, each including a variable (V) domain encoded after RAG-mediated recombination of Ig gene segments (for review [23]). Within mIgs, constant (C) regions carry additional transmembrane and cytoplasmic domains which support interactions with Iga/ $/$ and then accessory receptors and downstream intracellular signaling cascades including the src kinases Syk, Lyn and adaptor proteins such as BLNK for interactions with PLC $\gamma 2$, PI3K, calcium and glucose transporters. IgH C domains confer their class specific effector functions to the corresponding

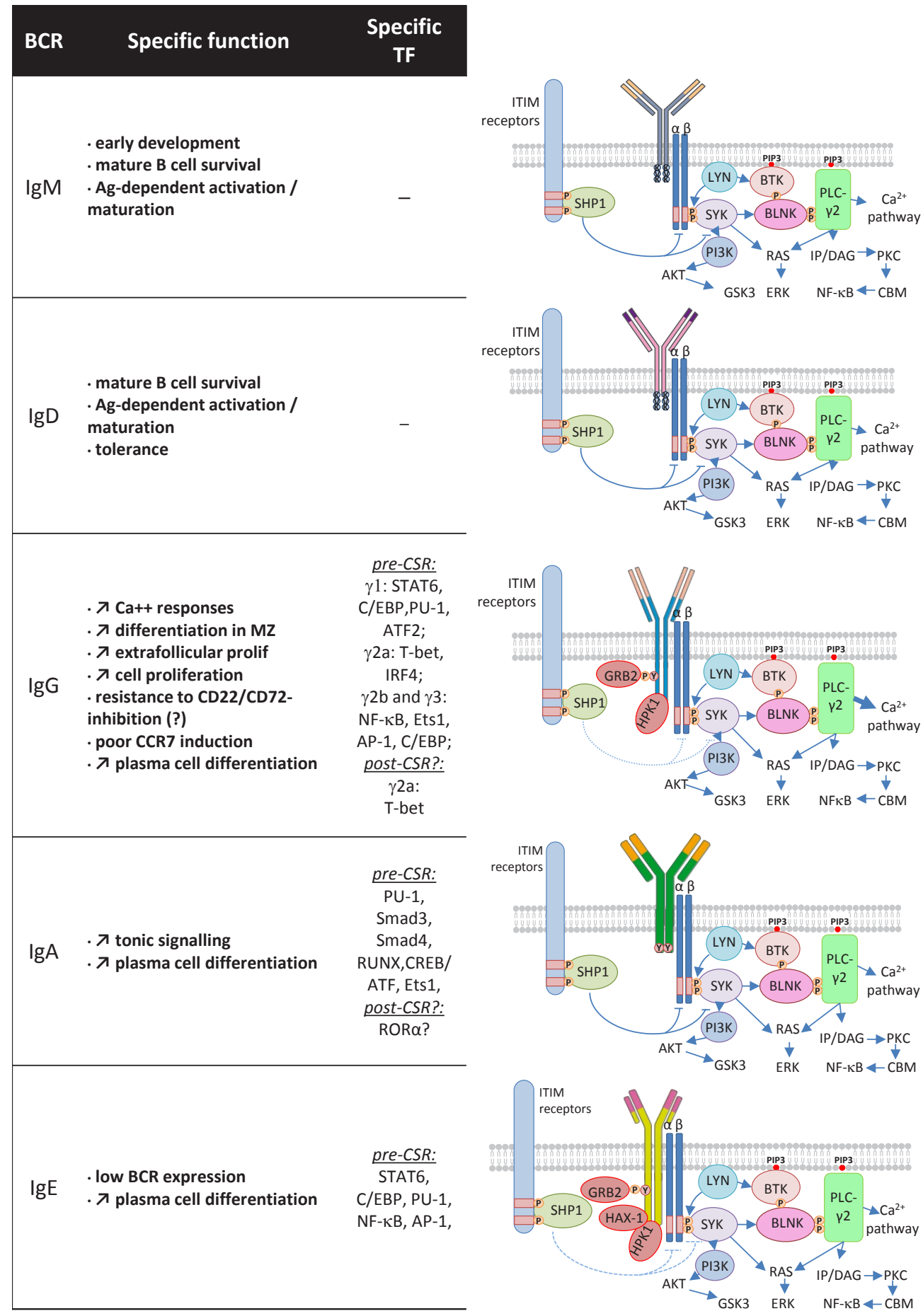

Figure 2: BCR class and signaling cascades. Some specific functions of the various BCR classes are indicated (left). Specific transcription factors expressed before CSR to a given class (and eventually after CSR) are mentioned (middle). Each BCR class is represented as a membrane Ig associated with the Iga/ß signaling modules (right). The three amino acids (KVK) of the IgM and IgD BCR and longer intra-cytoplasmic tails of other classes are shown. The main signaling proteins and pathways that are common or most likely specific to these BCR classes are represented (right). 
secreted Ig.

\subsection{IgM/IgD BCR}

While all $\mathrm{mIg}$ associate with the Iga/ $/$ complex to constitute the $\mathrm{BCR}$, signaling from this complex has mostly been studied for IgM [24][25]. The membrane $\mu$ $\mathrm{HC}$ has multiple roles by first providing differentiation signals during early development, survival signals in resting $\mathrm{B}$ cells and activation signals during peripheral antigen-dependent maturation (Figure 2). $\operatorname{IgM}$ and $\operatorname{IgD}$ have an identical intracellular positively charged short tail (including residues KVK). Replacement of $\mu$ by $\delta \mathrm{HC}$ expression resulted in a modest phenotype and suggested that $\operatorname{IgM}$ and $\operatorname{IgD}$ can signal in a roughly similar manner [26]. This replacement completely deleted both $\mathrm{mIgM}$ expression and secretion of soluble IgM. The main feature of the resulting phenotype was delayed affinity maturation of immune humoral responses, i.e. a phenotype similar to mice simply lacking the secreted form of IgM [26][27]. It was also shown later that, despite their roughly normal peripheral B cell compartments, mice in which $\mu \mathrm{HC}$ was replaced by $\delta \mathrm{HC}$ expression had a partial blockage of pro-B to pre-B transition due to lack of autonomous pre$\mathrm{BCR}$ signaling normally provided by a glycosylation site within the $\mu$ chain $\mathrm{CH} 1$ domain [28].

IgD-deficient mice have also been generated through gene targeting and only showed slightly reduced B-cell spleen and lymph node compartments with higher mIgM expression than wt B cells. Early and late B cell differentiation, $\mathrm{GC}$ formation and humoral responses to immunization were unaffected [29]. However, a later study showed autoantibodies accumulating in IgD-deficient/lpr mice, suggesting that $\mathrm{mIgD}$ plays a role in $\mathrm{B}$ cell tolerance and limits auto-reactive $\mathrm{B}$ cell differentiation into plasma cells [30].

\section{3. $\mathrm{mIgG} B C R$}

There are clear qualitative differences in BCR signaling and responses to antigen that are conferred by IgG vs IgM HC tails [31] (Figure 2). IgG carry longer

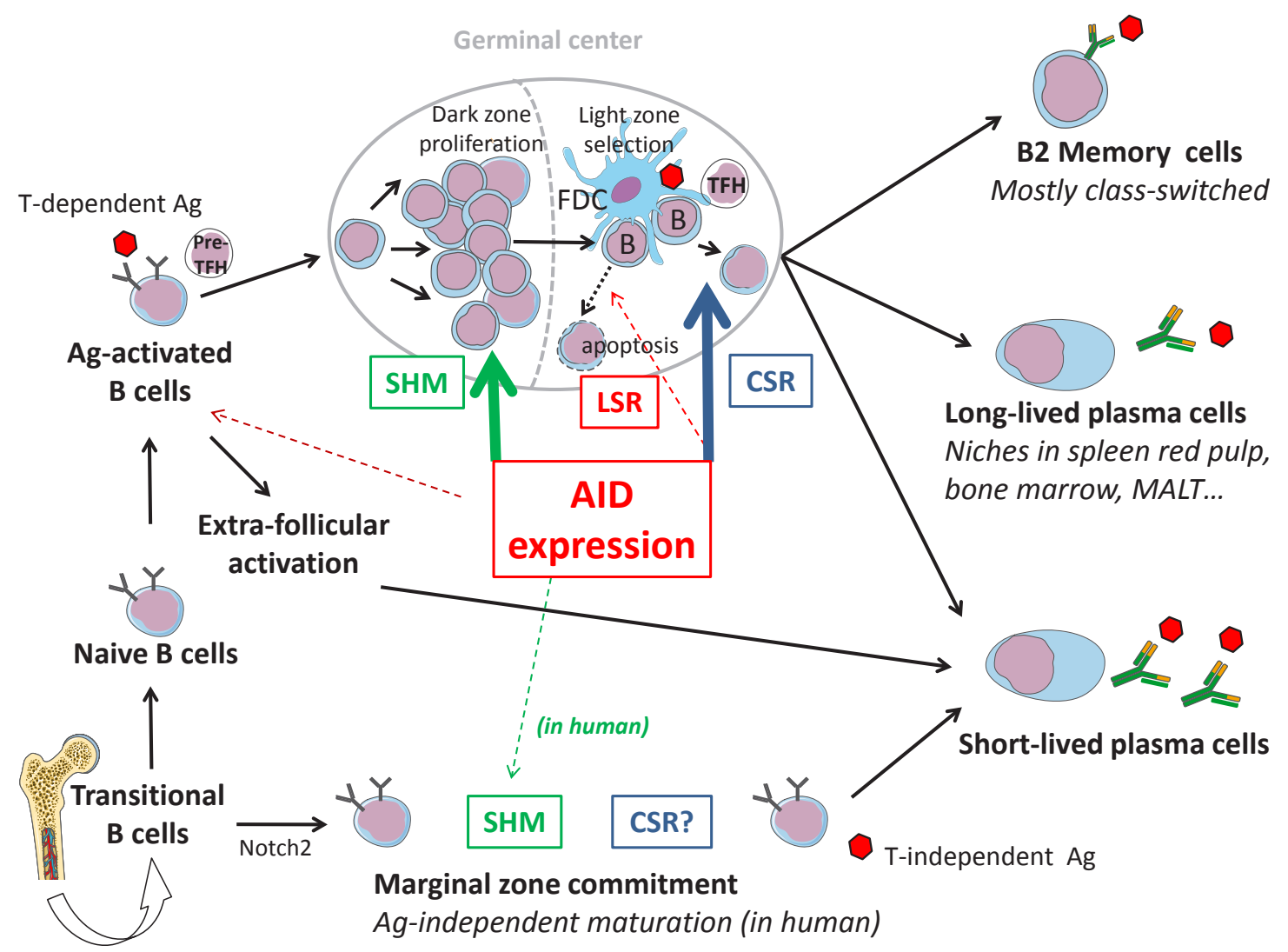

Figure 3: AID-modulation of B cell fate in the context of lymphoid tissues. After V(D)J recombination and IgM expression, recently emerged B cells circulate as transitional cells and can be committed to various compartments depending upon BCR signalling (Notch2 expression and weak BCR tonic signaling commit B cells to a marginal zone fate). After maturation into $\operatorname{IgM}+$, IgD + cells, naïve $\mathrm{B}$ cells encounter T-dependent Ag and undergo cognate interactions with pre-TFH cells. B cells then initially activate in extra-follicular foci and differentiate into short-lived plasma cells, or participate with TFH in the formation of GCs where their BCRs will be deeply remodeled by SHM (mostly in the proliferating dark zone) or CSR (mostly in the GC light zone), or eventually LSR. The GC reaction will yield both memory cells and plasma cells, some being long-lived and surviving after their migration to several protective niches (spleen red pulp, bone marrow, MALT...). 
and highly conserved cytoplasmic tails. Deletion or replacement of the $\operatorname{IgG}$ tail with an $\operatorname{IgM}$ tail in mice resulted, for unexplained reasons, in lower levels of membrane expression and also strikingly disturbed IgG1 memory, showing that the $\mathrm{IgG}$ tail is necessary for high-titer IgG secretion and IgG1-switched memory cell survival [32]. In contrast, studies in transgenic mice carrying IgM, IgG or IgM/G (IgM with an IgG tail) BCRs of identical antigen specificity for hen-egg lysozyme, showed that the $\operatorname{IgG}$ tail increased production of plasma cells during extra-follicular $\mathrm{T}$ cell-dependent antibody reactions [33]. It was also observed in $\mathrm{B}$ cell transfectants that signaling through the $\mathrm{mIgG}$ BCR, but not through mIgM nor mIgD, was resistant to CD22-mediated signal inhibition [34]. However, this CD22-independence was not confirmed by other detailed studies in primary cells from transgenic or knock-in mice [31][35]. Rather, it was then suggested that IgG enhancement of intracellular calcium responses did not reflect independence from CD22 inhibition or changes in tyrosine phosphorylation, ERK signaling, or global gene induction, but increased differentiation into marginal zone cells, extrafollicular proliferation, and plasma cell differentiation. Despite increased $\mathrm{Ca} 2+$ responses, several $\mathrm{BCR}$ ligation response genes showed lower induction by the IgG tail, in agreement with the observation that marginal zone $B$ cell differentiation is favored by conditions that decrease BCR signaling [36]. This includes poor CCR7 induction by antigen ligation of the $\operatorname{IgG~BCR}$, while before entry into follicles, CCR7 is known to attract B cells to CCL19/ CCL-21-rich T-zones rather than towards the marginal zone.

Premature expression of $\operatorname{IgG}$ rather than $\operatorname{IgM}$ in $\mathrm{B}$ cell progenitors also resulted in abnormal pre-BCR signaling and partial blockage of pro-B to pre-B cell transition, emphasizing that $\mathrm{mIgM}$ is optimal for early $\mathrm{B}$ cell maturation. In contrast, maintenance of $\mathrm{mIgG}+$ cells might be less dependent on Ig $\alpha / \beta$ than $\mathrm{mIgM}+$ cells [35]. These observations led Goodnow's group to propose a "less-is-more" hypothesis where decreased induction of some BCR response genes might increase plasma cell formation, and to globally conclude that signaling differences between IgG and IgM BCR classes were qualitative rather than quantitative [31].

In comparison to $\mathrm{IgM}$, another specific signaling feature of $\mathrm{mIgG}$ (shared with $\mathrm{mIgE}$ ), is recruitment of the adaptor Grb2, which can bind to a tyrosine of the $\mathrm{mIgG}$ intracellular tail upon phosphorylation, and then modulate signaling and increase cell proliferation [37]. Interestingly, Grb2 is a modulator of cell signaling by tyrosine kinase receptors, with the dual function, in some instances, to decrease basal signaling while increasing signals emanating from receptor ligation [38].

Another feature of the mIgG1 cytoplasmic tail was demonstrated: enhancing early BCR oligomerization that immediately follows ligation of membrane bound antigen leading to increased Syk recruitment and calcium mobilization [39]. Importantly, a recent study has shown that the strong tendency of mIgG1 cells to differentiate into plasma cells is restricted to those Ag-experienced cells and then translated into Bach2 repression, thus clearly involving more than just $\mathrm{mIgG}$ intracellular tail structure [40].

\section{4. $\mathrm{mIgA} B C R$}

Few studies have explored a potential role for mIgA in conferring specific properties to memory mIgA+ B cells in comparison to naive $\mathrm{mIgM}+$ cells (Figure 2). mIgA cross-linking raises intracellular calcium concentrations so that $\mathrm{mIgA}+\mathrm{B}$ cells residing in mucosa associated lymphoid tissues (MALT) can mediate IgA responses to local immunization [41][42]. As for IgG, it was also shown by targeted deletion in the mouse, that the $\mathrm{C} \alpha$ membrane anchoring region allowing mIgA expression, is necessary for differentiation of IgA secreting cells in vivo [43]. The $\mu \mathrm{MT}$ mutation removing $\mathrm{C} \mu$ membrane exons and $\mathrm{IgM} / \mathrm{IgD}$ expression did not result in a complete $\mathrm{B}$ cell defect but resulted in accumulation of $\operatorname{IgA}+$ plasma cells in MALT, also suggesting that B cell progenitors can undergo CSR to $\mathrm{mIgA}$, survive under expression of this BCR and then differentiate into ASCs [44]. That early $\mathrm{B}$ cell development can be ensured by expression of membrane $\alpha \mathrm{HC}$ has been shown in the $\alpha 1 \mathrm{KI}$ model where the $\mathrm{S} \mu$ region of the mouse $\mathrm{IgH}$ locus was replaced with an Ig $\mathrm{HC}$ al gene [45].

In $\alpha 1 \mathrm{KI}$ mice, a partial defect in pre-B cells was, however, noticed, indicating that the $\alpha$-class pre-BCR was less efficient than $\mu$-class pre-BCR for signaling completion of $\mathrm{V}(\mathrm{D}) \mathrm{J}$ rearrangement upon assembly of a functional pre-BCR or BCR complex. This was reminiscent of data in mice with premature expression of membrane $\gamma \mathrm{HC}$ instead of $\mu / \delta[35]$.

Despite this developmental defect, B cells accumulated in lymphoid organs of a1KI mice including spleen follicles, marginal zone, lymph nodes, Peyer's patches and the peritoneal B1 compartment. Splenic marginal zone and follicular B cell numbers were affected in the same proportion, in contrast to the increased marginal zone differentiation reported in mice expressing an IgG BCR $[31,35]$. As mentioned in a previous study [32], BCR density appeared lower in a1KI than in wt mice, despite normal association of $\mathrm{mIgA} 1$ with $\mathrm{Iga} / \AA$. Another feature of mIgA-driven B cell differentiation in a1KI mice was the abundance of plasma cells, affecting to the same extent long-lived (accumulated) and shortlived (recently differentiated) plasma cells. Rather than just compensatory plasma cell accumulation in response to B cell lymphopenia, the $\alpha 1 \mathrm{KI}$ intrinsic commitment to plasma cell differentiation was also manifested in vitro by 
higher differentiation of B cells activated by BCR crosslinking or mitogens into CD138+ cells.

Interestingly, normal human blood $\mathrm{mIgA}+$ cells also include a high proportion of CD38 expressing cells, a marker of engagement in plasma cell differentiation [46]. It should also be noticed that the IgA BCR has been shown to be sensitive to CD22 inhibition as for IgM [47]. In addition, a recent study demonstrated a specific transcriptional program for mIgA+ memory cells, notably depending upon high RORa expression, while mIgG2a+ cells were intrinsically dependent upon high expression of T-bet [48].

\section{5. $\mathrm{mIgE}$ BCR}

Secreted $\operatorname{IgE}$ is the least prevalent Ig class in blood, with only nanograms per milliliter compared to micrograms for $\mathrm{IgD}$ and milligrams for other classes in healthy populations. Maintaining low IgE levels is controlled by stringent mechanisms in order to restrict the very potent effects and side-effects of $\operatorname{IgE}$ immune responses. The IgE molecule is evolutionarily conserved and present in all mammalian species studied. In contrast to its active role in immune responses against parasites, IgE can also be deleterious and mediate atopic diseases of various intensities (eventually lethal in the case of anaphylactic shock).

Production of the double-sworded IgE antibody thus requires tight regulation, for which multiple mechanisms might be at work. IgE expression was first postulated to be restrained at the CSR level. Whereas IgG1 and IgE class switching can be both induced by IL4 in mice, in vitro experiments most often show lower switching frequency to $\mathrm{IgE}$ than to $\mathrm{IgG} 1$ [49]. Preferential CSR to $\mathrm{C} \gamma 1 \mathrm{might}$ thus reflect intrinsic differences between the $10 \mathrm{~kb}$-long $\mathrm{S} \gamma 1$ and the much shorter SE region. Furthermore, IgE class switching is often a sequential process with an IgG1 intermediate [50]. Interestingly, direct CSR to IgE (without prior IgG1 CSR) occurs preferentially in immature B cells, and this feature may reflect epigenetic marks modulating accessibility of the IgH locus during B cell differentiation [51].

Beyond IgE CSR, it is clear that expression of $\mathrm{mIgE}$ $\mathrm{BCR}$ is mandatory for further differentiation into $\mathrm{IgE}$ secreting plasma cells (Figure 2). Mice deleted for IgE membrane exons have reduced (by more than 95 percent) serum IgE levels and fail to develop antigen specific $\operatorname{IgE}$ responses [52]. To a milder extent, replacement of the $\operatorname{IgE}$ tail with the much shorter IgM tail also decreased ( $50 \%)$ $\operatorname{IgE}$ secretion [52]. It was also shown that treatment of mice with an antibody specifically targeting a mIgEspecific epitope on $\mathrm{mIgE}+$ cells efficiently inhibited secreted IgE production [53][54], further suggesting that $\mathrm{mIgE}+\mathrm{B}$ cells are a necessary step for differentiation of IgE secreting plasma cells.

In this regard, a structural feature of the $\mathrm{C} \varepsilon$ gene was postulated to restrain the production of membranetype $\mathrm{C} \varepsilon$ transcripts which drive $\mathrm{mIgE}$ expression. Whereas all documented Ig genes have classical polyA sites (AATAAA) after both their secretory (CH3 or $\mathrm{CH} 4)$ and membrane (M1/M2) exons, human and mouse $\mathrm{C} \varepsilon$ genes carry an atypical polyA site downstream from the M2 exon [55]. By comparing the sequence of $\mathrm{CE}$ genes in the IMGT data base (http://www.imgt.org), we observed that a canonical AATAAA sequence downstream from CE M2 was absent in all published mammalian IgH loci. This conserved suboptimal polyA site may down-regulate the ratio of membrane- vs secreted-form $\mathrm{C} \varepsilon$ mRNA transcripts during alternative splicing of murine (and human) $\mathrm{C} \varepsilon$ primary transcripts [56] and thus limit mIgE BCR expression. In an utmost form, $\mathrm{C} \mathcal{E}$ gene membrane exons are lacking in one lineage of primates, the tarsiers [55].

Despite these limitations, mIgE expression can be characterized in vitro in human or mouse stimulated B cells and has also been characterized in a B lymphoma cell line [57]. Exploring mIgE expression requires rigorous staining protocols eliminating passive binding of soluble IgE to FceRII receptors (whose expression is strongly induced in the presence of IL4) [58].

While present in a single (short) form in most mammalian species, $\mathrm{mIgE}$ is additionally present in humans and apes as a long isoform generated through alternate splicing of the M1 exon, and including either a long (66 amino acids) or a short (14 amino acids) extracellular membrane proximal domain (EMPD) between $\mathrm{CH} 4$ and the transmembrane domain. Both human $\mathrm{mIgE}$ isoforms have been expressed as functional BCRs in transfected B cells, showing that the short isoform was more efficiently transported to the cell surface and that its ligation resulted in growth inhibition of the WEHI immature B cell line, similar to mIgM BCR [59]. The EMPD domain was shown to be necessary for B cell activation through $\mathrm{mIgE}$ ligation in transfectants from the mature B cell line A20, while its deletion yielded a form of $\mathrm{mIgE}$ with proapoptotic activity upon ligation [60].

Another particularity of the IgE BCR is the intracellular tail structure, and phage display experiments identified 2 proteins interacting with the IgE tail. HS1associated protein X-1 (HAX-1) notably seems to be associated with the IgE specific YANIL motif (where $Y$ is a potentially phosphorylated tyrosine) of the intra-cellular tail and may influence BCR mediated Ag-internalization and cognate Ag-presentation to T cells [61]. Hematopoietic progenitor kinase 1 (HPK1) was also shown to interact with $\mathrm{mIgE}$ and $\mathrm{mIgG}$ (but not $\mathrm{mIgM}$ ) tails and could differentially affect signaling from these receptors [62]. IgE committed B cells were also shown to be exquisitely sensitive to inhibition through ligation of LXR receptors, potentially due to increased CD23 expression and in turn down-regulating IgE production [63].

In order to study IgE responses in vivo, different mouse models have been developed and characterized. 
Xiong et al used $\mathrm{T}$ and $\mathrm{B}$ monoclonal mice (with antichicken ovalbumin (OVA) $\mathrm{T}$ cell receptor transgenes and anti-influenza hemagglutinin (HA) knock-in B cell receptor genes on a RAG1-deficient background), immunized with OVA-HA and OVA-PEP1 (a variant of HA) and a classical model of helminth infection in wt mice. They showed that $\operatorname{IgE}+$ cells were found outside the GC (in contrast to IgG1 cells) and displayed a plasma cell transcriptional program. They also showed that IgEs accumulate hypermutation and affinity selection (and are able to bind the PEP1 Ag) and proposed a sequential maturation program: a pre-IgE phase with SHM and affinity maturation in IgG1+ cells and a post-IgEswitching phase where $\mathrm{IgE}+$ rapidly differentiate into plasma cells [64]. In another study this team used the same T/B monoclonal model and immunized wt or hMT mice (which are deficient for IgG1 populations) with NP19KLH Ag. They demonstrated that high affinity $\operatorname{IgE}$ Abs responsible for anaphylactic reactions were generated through the sequential $\mu / \gamma 1 / \mathcal{E}$ CSR pathway (and were absent in hMT mice), with IgG1 intermediate cells supporting SHM and affinity selection. In contrast, low affinity IgE producing cells were generated through direct $\mu / \mathcal{E}$ CSR, were less mutated, and may play a beneficial role during anaphylaxis, by competing with high affinity $\mathrm{Ab}$ for FcER1 binding [65].

Two transgenic models were created to study rare $\mathrm{IgE}+$ cells in vivo. The first model used a GFP reporter system by inserting a bi-cistronic GFP reporter gene downstream from the mouse IgE M2 exon. The long human EMPD domain was introduced upstream to the IgE M1 exon, resulting in a chimeric IgE BCR with an additional EMPD domain (allowing specific detection of these cells but denaturing the natural architecture of this receptor). This model was subjected to helminth infection by N. brasiliensis and TNP-OVA immunization. In contrast to previous models, this strategy demonstrated $\mathrm{IgE}+$ cells in $\mathrm{GC}$ and suggested the existence of $\mathrm{IgE}+$ memory and plasma cells [66]. In another model, the T2A strategy tagged $\mathrm{IgE}+$ cells by linking the $\mathrm{C} \varepsilon \mathrm{M} 2$ exon with Venus (a derivative of yellow fluorescent protein) and used a viral $2 \mathrm{~A}$ sequence enabling expression of 2 proteins from a single ORF. Translation of Venus was thus linked to translation of a nearly normal mIgE (except for an additional 17 amino acid peptide). These mice and wt mice were immunized with NP-KLH and infected with $\mathrm{N}$. brasiliensis. This model suggested that IgE + cells can differentiate into GC B cells during primary immune responses and confirmed a strong propensity of these cells to differentiate rapidly into plasma cells which were mostly short-lived [67]. In agreement with this conclusion, another model where membrane IgE exons were replaced by membrane IgG1 exons suggested that $\mathrm{IgE}+$ plasma cells have an intrinsically lower chance than IgG1+ cells to migrate towards the chemokine CXCL12 and thus to contribute to the long-lived plasma cell pool [68].

\section{LSR ELIMINATION OF B CELLS}

B cell fate can also be more dramatically modified by AID after CSR-like events resulting in complete deletion of the $\mathrm{IgH} \mathrm{CH}$ gene cluster and thus inducing B cell death through locus suicide recombination (LSR) (Figure 1) [16].

During AID-mediated competition that occurs among B cells within germinal centers, a few with high affinity are selected (Figure 3). Besides these winners, many cells are losers or undesired responders deserving elimination. Although some unfavorable mutations of $\mathrm{V}$ regions can promote apoptosis [69], abundant survival signals from the GC microenvironment might also activate or maintain bystander cells with useless or eventually harmful BCRs (the latter having, for example, acquired specificity for self or environmental antigens after random remodeling of $\mathrm{V}$ sequences). Since class-switched antibodies are potent actors of auto-immunity and/or hypersensitivity, means for restricting CSR and reentry of class-switched cells into SHM would help ensure the specificity of immune responses. Yet, how the post-GC repertoire is controlled remains poorly understood.

The 3'RR contains several enhancers with strong B-lineage specificity [70,71] undergoing chromatin remodeling upon $\mathrm{B}$ cell activation and controlling $\mathrm{V}$ region SHM as well as germline transcription and CSR to most $\mathrm{C}$ genes [72-83]. In all mammalian species studied, the 3'RR also features inverted repeats and stretches of repetitive DNA with structures similar to that of $\mathrm{S}$ regions [84-87], showing multiple 5bp repeats eventually arranged within higher order (49bp) repeats. Such "like S" stretches (LS regions) flank both sides of the 3'RR and are also interspersed with 3 ' enhancers. Similarly to the germline transcription of $\mathrm{S}$ regions preceding CSR, the 3'RR is transcribed by RNA polymerase II in activated $\mathrm{B}$ cells [88].

3'RR elements regulate AID-mediated SHM and CSR by physically interacting with AID-targeted $\mathrm{IgH}$ promoters [70, 74, 79, 80, 89]. Since 3'RR enhancer elements and LS regions are themselves transcribed, it was logically found that they also undergo SHM and DNA breaks. AID-initiated junctions then occur in activated B cells between $\mathrm{S} \mu$ and 3'RR LS regions and delete the complete $\mathrm{C}$ gene cluster, thereby eliminating BCR expression (or Ig secretion for cells engaged in plasma cell differentiation). Given that BCR expression is mandatory for B cell survival, this process termed "locus suicide recombination" (LSR) necessarily leads to B cell death.

How the CSR/LSR balance is finely regulated in vivo remains to be determined. Beyond $\mathrm{IgH}$ locus accessibility, intra-GC interactions govern the selection of high affinity class-switched cells. In this context, LSR might contribute to B cell homeostasis and lead to death of suboptimally stimulated cells, while optimal stimulation would promote CSR and survival of selected 
antigen-specific B cell clones. LSR could then help shape the peripheral B cell repertoire and ensure BCR antigen specificity.

\section{DEVELOPMENT AND FEATURES OF MEMORY B CELLS}

$\mathrm{B}$ cell responses to T-dependent antigens involve germinal center reactions featuring $\mathrm{B}$ cell proliferation and expression of AID for SHM and CSR in parallel interactions with follicular dendritic cells and $\mathrm{T}$ follicular helper cells that will help select those B cells with the highest affinity for Ag. GC reactions peak after 7 days and wane after a few weeks, once having generated long-lived plasma cells and memory B cells with an affinity matured BCR. Besides intra-GC competition between B cells for limited antigen, soluble antibody feedback also ensures inter-GC communication concerning access to antigen [90]. Secreted antibodies were thus shown to inhibit or even terminate GC proliferation with an efficiency directly correlated with their affinity for antigen [90]. Interestingly in the absence of $\mathrm{T}$ cell help, soluble antigen might also inhibit GC development [91].

Regarding the prolonged maintenance (eventually lifelong) of GC-born memory B cells, it was shown that Ag-persistence within lymphoid organs is unnecessary [92]. Rather, further reintroduction of $\mathrm{Ag}$ into the organism will trigger memory cell differentiation into plasma cells, with or without parallel formation of new GC [93]. A recent study by Reynaud and colleagues followed Ag-specific memory B cells for up to 1 year in mice and showed that while GCs waned a few weeks after immunization by a soluble antigen, they persisted up to 10 months after immunization with a particulate $\mathrm{Ag}$ [94]. Several types of memory cells were demonstrated in the latter model: either $\operatorname{IgM}+\operatorname{IgD}+$, or IgM-only, or classswitched (and then mostly mIgG1+). Ag-experienced cells were located in the spleen $\mathrm{T}$ cell zone, red pulp, and follicles, with very few in the marginal zone. Upon transfer into pre-immunized recipient animals, the $\mathrm{mIgM}+$ subset gave rise to centroblasts, part of them switching to IgG1, and to a small proportion of Ag-specific IgM+ plasma cells. The mIgG1 subset yielded Ag-specific IgG1 plasma cells and maintenance of a mIgG1+ memory pool. While the average number of mutations was stable in persisting memory B cells, it was increased upon differentiation of $\mathrm{mIgM}+$ memory cells into centroblasts, showing that such cells can reenter new cycles of AID-mediated affinity maturation.

In another model, two layers of Ag-specific B memory cells were demonstrated, either $\mathrm{mIgM}+$ or having undergone class switching (swIg + memory cells). The mIgM + memory cells were very stable and long-lived, able to form $\mathrm{GC}$ when transferred into a naïve animal but inhibited upon the presence of soluble Ag-specific Ig (then inhibiting GC formation). The swIg+ memory cells persisted for a shorter time, and mostly differentiated into plasmablasts upon activation but kept the ability to be activated even in the presence of preexisting antibodies. This led to the proposition that memory 1) initially relies on swIg + cells, able to be rapidly activated and yield antibodies even in the presence of preexisting serum antibodies, and 2) later relies on longlived mIgM+ memory cells, able to form new GC once initial antibodies have vanished [93]. If this model can be generalized, "early" memory responses would classically overwhelmingly involve class-switched antibodies, while "late" memory responses would be expected to recapitulate the kinetics of the primary response, first with IgM (albeit with low affinity) then followed with high affinity classswitched antibodies. Interestingly, it was recently shown in a model of bacterial infection that in vivo depletion of the mIgM memory B cells abrogated the IgG recall responses to specific Ag challenge, demonstrating that mIgM cells were then required for humoral memory, and underwent CSR and plasma cell differentiation upon $\mathrm{Ag}$ re-challenge [95].

Upstream of GC reactions, some specific functions have been reported during immune responses for B cells with low affinity BCRs. For example, mouse B1 cells show polyreactivity and bind multiple exogenous antigens or auto-antigens with low affinity, being responsible for generation of natural antibodies that preexist prior to any antigenic challenge and play an innate function. Some tissue $\mathrm{B}$ cells binding antigens with low affinity (notably in lung, with intra-nasally administered antigens) have also been demonstrated to shuttle and carry antigens towards spleen follicles, then initiating GC formation by resident $B$ cells with higher affinities [96]. BCR independent Ag-binding by $\mathrm{B}$ cells was also reported for marginal zone $\mathrm{B}$ cells recognizing particulate antigens within immune complexes through complement or $\mathrm{Fc}$ receptors, which were also postulated to carry antigens towards FDCs within follicles [97]. Human and mouse MZ B cells might somehow differ although they both respond to T-independent antigens. While mouse MZ B cells have mostly unmutated BCRs and do not recirculate, human $\operatorname{IgM}+\operatorname{IgD}+\mathrm{CD} 21$ highCD27+ B cells recirculate in blood and carry mutated Ig and Bcl6 genes. Their V(D) $\mathrm{J}$ repertoire is very large without clonal restrictions and hallmarks of antigen-induced activation, similar to naive cells and in contrast to $\mathrm{GC} \mathrm{mIgM+} \mathrm{cells,} \mathrm{suggesting} \mathrm{that}$ MZ B cells provide a GC-independent IgM memory layer [98]. MZ B cells likely differentiate through an innate extracellular TLR-dependent pathway allowing AID induction outside GC, as demonstrated in both mouse and humans for immature B cells then undergoing CSR and SHM [99][7]. A helper role for neutrophils in the induction of MZ B cell CSR, SHM and plasma cell differentiation was also demonstrated during T-independent responses to bacterial antigens [100]. 


\section{LYMPHOMAGENESIS AND BCR SIGNALS}

AID also induces mutations and breaks in numerous non-Ig genes, many of which (but not all) are transcribed in B cells, and many of which overlap with translocation or recombination sites found in B cell lymphomas or correspond to repetitive DNA sequences. [101,102]. Studies of B cell malignancies since the early 1980s also identified a number of translocations linking oncogenes such as c-MYC, c-MAF, CYCLIN D1, and BCL2 to breakpoints located within Ig loci. Some of these events were recurrently identified as the clonal driving forces of lymphomagenesis. This pointed to a major role of errors in the processes of antibody gene diversification in tumorigenesis. Recently, it was also shown that breakpoints located outside Ig loci constitute frequent side targets of AID attacks in activated B cells. It is thus now clear that in B cell malignancies as in normal B cells, AIDinduced mutations accumulate on multiple loci including those of Ig (with the higher level of error-prone repair after AID deamination), BCL6 and a large list of oncogenes and tumor suppressors.[101] Precise characterization of translocation breakpoints and development of whole genome sequencing showed that mutations and recombinations detected in activated $\mathrm{B}$ cells and in tumors with mature B cell phenotypes all carry hallmarks of WRC sequence-specific AID on-target and off-target attacks. $[103,104]$ In addition, more than half of translocations seen in immature B cell malignancies also show breakpoints at sites of AID deamination corresponding to $\mathrm{mCG}$ dinucleotides and might imply the combined action of AID, RAG and ARTEMIS. [105,106] However, this issue can still be debated and it is noteworthy that lymphoma breakpoints targeting CG dinucleotides were also recently identified by A. Nussenzweig and colleagues, as early replicating fragile sites susceptible to AIDindependent genomic instability [107].

Besides the role of translocations, it is important to note that BCR signals most likely play a crucial role in lymphomagenesis. These signals might vary with SHM of $\mathrm{V}$ regions, which probably modulate interactions of malignant cells with various endogenous ligands. Indeed, $\mathrm{N}$-glycosylation sites carrying high-mannose glycans and created by SHM within V domains are a frequent feature of follicular lymphoma cells, and may promote B cell interactions with lectins such as DC-SIGN [108]. The BCR Ig class might also somehow control the phenotype of B cell malignant proliferations. Indeed, it is well known that plasmacytic lymphomas overwhelmingly express mIgM (in striking contrast with myelomas, where the secreted Ig is always a non-IgM class). In diffuse large $B$ cell lymphomas, it was recently shown that $\mathrm{ABC}$ cases mostly express $\mathrm{mIgM}$, while GC cases overwhelmingly express IgG or IgA [109].

Autonomous BCR signaling in chronic lymphocytic leukemia cases was also recently demonstrated, but appeared independent from the mutated or unmutated BCR status [110].

Finally a number of AID-mediated mutations affecting proteins of BCR- or TLR-signaling cascades and resulting in constitutive $\mathrm{B}$ cell activation have been observed in many different types of lymphoproliferation $[111,112]$.

\section{CONCLUSIONS}

Early B cell differentiation is optimally driven through expression of germinally encoded and diversified IgM molecules. This generates transitional B cells that are affected to the various mature B cell compartments and then express variable levels of $\operatorname{IgM}$ and $\operatorname{IgD}$. Such cells can then undergo either Ag-dependent (within B cell follicles) or Ag-independent (for splenic marginal zone B cells), AID remodeling of their Ig V regions through SHM or GCV. Cell survival, fate and phenotype are all highly dependent at that time on constitutive signals provided by the BCR. Either antigen ligation of the BCR and/or stimulation by various TLR ligands can additionally result in B cell activation and rapid AID induction. By improving BCR affinity for antigen by SHM, AID will help select follicular cells having the strongest interactions with antigen exposed at the surface of FDC along the process of SHM, as winners of the competition for activation and survival signals provided by FDC and TFH cells within the GC. In parallel, these interactions further stimulate expression and accessibility of the $\mathrm{IgH}$ locus then resulting in CSR for expression of a new BCR with conserved Ag-specificity but new signaling functions. Finally in some instances, another dramatic IgH remodeling event implying complete deletion of the IgH locus $\mathrm{C}$ region through a "sterile CSR" (also defined as "locus suicide recombination" or LSR), can occur and result in loss of $\mathrm{BCR}$ expression and B cell death.

\section{ACKNOWLEDGMENTS}

Our work mentioned in this review was supported by grants from Agence Nationale de la Recherche (ANR), Ligue contre le Cancer and Association pour la Recherche sur le Cancer (Grant SL220100601332).

\section{REFERENCES}

1. Conticello SG, Thomas CJ, Petersen-Mahrt SK, Neuberger MS. Evolution of the AID/APOBEC family of polynucleotide (deoxy)cytidine deaminases. Molecular Biology and Evolution. 2005; 22:367-377.

2. Muramatsu M, Sankaranand VS, Anant S, Sugai M, Kinoshita K, Davidson NO, Honjo T. Specific expression of activation-induced cytidine deaminase (AID), a novel 
member of the RNA-editing deaminase family in germinal center B cells. Journal of Biological Chemistry. 1999; 274: 18470-18476.

3. Muramatsu M, Kinoshita K, Fagarasan S, Yamada S, Shinkai Y, Honjo T. Class switch recombination and hypermutation require activation-induced cytidine deaminase (AID), a potential RNA editing enzyme Cell. 2000; 102:553-563.

4. Revy P, Muto T, Levy Y, Geissmann F, Plebani A, Sanal O, Catalan N, Forveille M, Dufourcq-Labelouse R, Gennery A, Tezcan I, Ersoy F, Kayserili H, Ugazio AG, Brousse N, Muramatsu M, Notarangelo LD, Kinoshita K, Honjo T, Fischer A, Durandy A. Activation-induced cytidine deaminase (AID) deficiency causes the autosomal recessive form of the Hyper-IgM syndrome (HIGM2). Cell. 2000; 102: 565-575.

5. Pavri R, Nussenzweig MC. AID targeting in antibody diversity. Advances in Immunology. 2011; 110: 1-26.

6. Liljavirta J, Ekman A, Knight JS, Pernthaner A, Iivanainen A, Niku M. Activation-induced cytidine deaminase (AID) is strongly expressed in the fetal bovine ileal Peyer's patch and spleen and is associated with expansion of the primary antibody repertoire in the absence of exogenous antigens. Mucosal Immunology. 2013.

7. Han JH, Akira S, Calame K, Beutler B, Selsing E, Imanishi-Kari T. Class switch recombination and somatic hypermutation in early mouse B cells are mediated by B cell and Toll-like receptors. Immunity. 2007; 27: 64-75.

8. Kuraoka M, Holl TM, Liao D, Womble M, Cain DW, Reynolds AE, Kelsoe G. Activation-induced cytidine deaminase mediates central tolerance in B cells. Proceedings of the National Academy of Sciences of the United States of America. 2011; 108: 11560-11565.

9. Maul RW, Gearhart PJ. AID and somatic hypermutation. Advances in Immunology. 2010; 105:159-191.

10. Pavri R, Gazumyan A, Jankovic M, Di Virgilio M, Klein I, Ansarah-Sobrinho C, Resch W, Yamane A, Reina SanMartin B, Barreto V, Nieland TJ, Root DE, Casellas R, Nussenzweig MC. Activation-induced cytidine deaminase targets DNA at sites of RNA polymerase II stalling by interaction with Spt5. Cell. 2010; 143: 122-133.

11. Willmann KL, Milosevic S, Pauklin S, Schmitz KM, Rangam G, Simon MT, Maslen S, Skehel M, Robert I, Heyer V, Schiavo E, Reina-San-Martin B, Petersen-Mahrt SK. A role for the RNA pol II-associated PAF complex in AID-induced immune diversification. Journal of Experimental Medicine. 2012; 209: 2099-2111.

12. Cogné M, Lansford R, Bottaro A, Zhang J, Gorman J, Young F, Cheng HL, Alt FW. A class switch control region at the 3' end of the immunoglobulin heavy chain locus. Cell. 1994; 77: 737-747.

13. Pinaud E, Khamlichi AA, Le Morvan C, Drouet M, Nalesso V, Le Bert M, Cogné M. Localization of the 3' IgH locus elements that effect long-distance regulation of class switch recombination. Immunity. 2001; 15: 187-199.

14. Pinaud E, Marquet M, Fiancette R, Péron S, Vincent-Fabert C, Denizot Y, Cogné M. The IgH locus 3' regulatory region: pulling the strings from behind. Advances in Immunology. 2011; 110: 27-70.

15. Vincent-Fabert C, Fiancette R, Pinaud E, Truffinet V, Cogné N, Cogné M, Denizot Y. Genomic deletion of the whole $\operatorname{IgH} 3$ ' regulatory region (hs3a, hs 1,2, hs $3 \mathrm{~b}$, and hs4) dramatically affects class switch recombination and Ig secretion to all isotypes. Blood. 2010; 116: 1895-1898.

16. Peron S, Laffleur B, Denis-Lagache N, Cook-Moreau J, Tinguely A, Delpy L, Denizot Y, Pinaud E, Cogne M. AID-Driven Deletion Causes Immunoglobulin Heavy Chain Locus Suicide Recombination in B Cells. Science. 2012; 336: 931-934.

17. Vuong BQ, Chaudhuri J. Combinatorial mechanisms regulating AID-dependent DNA deamination: Interacting proteins and post-translational modifications AID Insights Immune Diversif Cancer 2012, 24, 264-272

18. Di Virgilio M, Callen E, Yamane A, Zhang W, Jankovic M, Gitlin AD, Feldhahn N, Resch W, Oliveira TY, Chait BT, Nussenzweig A, Casellas R, Robbiani DF, Nussenzweig MC. Rif1 prevents resection of DNA breaks and promotes immunoglobulin class switching Science. 2013; 339: 711715 .

19. Jankovic M, Feldhahn N, Oliveira TY, Silva IT, KiefferKwon KR, Yamane A, Resch W, Klein I, Robbiani DF, Casellas R, Nussenzweig MC .53BP1 Alters the Landscape of DNA Rearrangements and Suppresses AID-Induced B Cell Lymphoma. Molecular Cell. 2013; 49: 623-31.

20. Bothmer A, Robbiani DF, Di Virgilio M, Bunting SF, Klein IA, Feldhahn N, Barlow J, Chen HT, Bosque D, Callen E, Nussenzweig A, Nussenzweig MC. Regulation of DNA end joining, resection, and immunoglobulin class switch recombination by 53BP1. Molecular Cell. 2011; 42: 319329.

21. Wuerffel R, Wang L, Grigera F, Manis J, Selsing E, Perlot T, Alt F W, Cogne M, Pinaud E, Kenter A. S-S synapsis during class switch recombination is promoted by distantly located transcriptional elements and activation-induced deaminase. Immunity. 2007; 27: 711-722.

22. Rouaud P, Vincent-Fabert C, Saintamand A, Fiancette R, Marquet M, Robert I, Reina-San-Martin B, Pinaud E, Cogné M, Denizot Y. The IgH 3' regulatory region controls somatic hypermutation in germinal center B cells. Journal of Experimental Medicine. 2013; 210: 1501-1507.

23. Nishana M, Raghavan SC. Role of recombination activating genes in the generation of antigen receptor diversity and beyond. Immunology. 2012; 137: 271-281.

24. Venkitaraman AR, Williams GT, Dariavach P, Neuberger MS. The B-cell antigen receptor of the five immunoglobulin classes. Nature. 1991; 352: 777-781.

25. Reth M, Wienands J. Initiation and processing of signals from the B cell antigen receptor. Annual Review of 
Immunology. 1997; 15: 453-479.

26. Lutz C, Ledermann B, Kosco-Vilbois MH, Ochsenbein AF, Zinkernagel RM, Köhler G, Brombacher F. IgD can largely substitute for loss of IgM function in B cells. Nature. 1998; 393: 797-801.

27. Ehrenstein MR, O'Keefe TL, Davies SL, Neuberger MS. Targeted gene disruption reveals a role for natural secretory $\mathrm{IgM}$ in the maturation of the primary immune response. Proceedings of the National Academy of Sciences of the United States of America. 1998; 95: 10089-10093.

28. Übelhart R, Bach MP, Eschbach C, Wossning T, Reth $\mathrm{M}$, Jumaa H. N-linked glycosylation selectively regulates autonomous precursor BCR function. Nature Immunology. 2010; 11: 759-765.

29. Nitschke L, Kosco MH, Köhler G, Lamers MC. Immunoglobulin D-deficient mice can mount normal immune responses to thymus-independent and -dependent antigens Proceedings of the National Academy of Sciences of the United States of America.1993; 90: 1887-1891.

30. Guo L, Tian J, Guo Z, Zheng B, Han S. The absence of immunoglobulin D B cell receptor-mediated signals promotes the production of autoantibodies and exacerbates glomerulonephritis in murine lupus. Clinical and Experimental Immunology. 2011; 164: 227-235.

31. Horikawa K, Martin SW, Pogue SL, Silver K, Peng K, Takatsu K, Goodnow CC. Enhancement and suppression of signaling by the conserved tail of IgG memory-type B cell antigen receptors. Jornal of Experimental Medicine. 2007; 204: 759-769.

32. Kaisho T, Schwenk F, Rajewsky K. The Roles of $\gamma 1$ Heavy Chain Membrane Expression and Cytoplasmic Tail in IgG1 Responses. Science. 1997; 276: 412-415.

33. Martin SW, Goodnow CC. Burst-enhancing role of the IgG membrane tail as a molecular determinant of memory. Nature Immunology. 2002; 3: 182-188.

34. Wakabayashi C, Adachi T, Wienands J, Tsubata TA. Distinct Signaling Pathway Used by the IgG-Containing B Cell Antigen Receptor. Science. 2002; 298: 2392-2395.

35. Waisman A, Kraus M, Seagal J, Ghosh S, Melamed D, Song J, Sasaki Y, Classen S, Lutz C, Brombacher F, Nitschke L, Rajewsky K. IgG1 B cell receptor signaling is inhibited by CD22 and promotes the development of B cells whose survival is less dependent on Ig $\alpha / \beta$. Journal of Experimental Medicine. 2007; 204: 747-758.

36. Pillai S, Cariappa A, Moran S T Marginal zone B cells. Annual Review in Immunology. 2005; 23: 161-196.

37. Engels N, König LM, Heemann C, Lutz J, Tsubata T, Griep $\mathrm{S}$, Schrader V, Wienands J. Recruitment of the cytoplasmic adaptor Grb2 to surface IgG and IgE provides antigen receptor-intrinsic costimulation to class-switched B cells. Nature Immunology. 2009; 10: 1018-1025.

38. Belov AA, Mohammadi M. Grb2 a double-edged sword of receptor tyrosine kinase signaling. Science Signaling. 2012; 5: 49 .
39. Liu W, Meckel T, Tolar P, Sohn HW, Pierce S K. Intrinsic properties of immunoglobulin IgG1 isotype-switched B cell receptors promote microclustering and the initiation of signaling Immunity. 2010. 32: 778-789.

40. Kometani K, Nakagawa R, Shinnakasu R, Kaji T, Rybouchkin A, Moriyama S, Furukawa K, Koseki H, Takemori T, Kurosaki T. Repression of the Transcription Factor Bach2 Contributes to Predisposition of IgG1 Memory B Cells toward Plasma Cell Differentiation. Immunity. 2013; 39: 136-147.

41. Leduc I, Drouet M, Bodinier M C, Helal A, Cogné M. Membrane isoforms of human immunoglobulins of the A1 and A2 isotypes: structural and functional study Immunology. 1997; 90: 330-336.

42. Brandtzaeg P, Baekkevold ES, Farstad IN, Jahnsen FL, Johansen F E, Nilsen E M, Yamanaka T. Regional specialization in the mucosal immune system: what happens in the microcompartments? Immunology Today. 1999; 20: 141-151.

43. Amin R, Carrion C, Decourt C, Pinaud E, Cogné M. Deletion of the $\alpha$ immunoglobulin chain membraneanchoring region reduces but does not abolish IgA secretion. Immunology 2012; 136: 54-63.

44. Hasan M, Polic B, Bralic M, Jonjic S, Rajewsky $\mathrm{K}$ Incomplete block of $\mathrm{B}$ cell development and immunoglobulin production in mice carrying the muMT mutation on the BALB/c background. European Journal of Immunology. 2002; 32: 3463-3471.

45. Duchez S, Amin R, Cogné N, Delpy L, Sirac C, Pascal V, Corthésy B, Cogné M. Premature replacement of mu with alpha immunoglobulin chains impairs lymphopoiesis and mucosal homing but promotes plasma cell maturation. Proceedings of the National Academy of Sciences of the United States of America. 2010; 107: 3064-3069.

46. Irsch J, Irlenbusch S, Radl J, Burrows PD, Cooper MD, Radbruch AH. Switch recombination in normal IgA1+ B lymphocytes. Proceedings of the National Academy of the Sciences of the United States of America. 1994; 91: 13231327.

47. Sato M, Adachi T, Tsubata T. Augmentation of signaling through BCR containing IgE but not that containing IgA due to lack of CD22-mediated signal regulation. Journal of Immunology. 2007; 178: 2901-2907.

48. Wang NS, McHeyzer-Williams LJ, Okitsu SL, Burris TP, Reiner SL, McHeyzer-Williams MG. Divergent transcriptional programming of class-specific B cell memory by T-bet and ROR $\alpha$. Nature Immunology. 2012; 13: 604-611.

49. Siebenkotten G, Esser C, Radbruch A, Wabl M. The murine $\operatorname{IgG} 1 / \mathrm{IgE}$ class switch program. European Journal of Immunology. 1992; 22: 1827-1834.

50. Jung S, Siebenkotten G, Radbruch A. Frequency of immunoglobulin E class switching is autonomously determined and independent of prior switching to other 
classes. Journal of Experimental Medicine. 1994; 179: 2023.

51. Wesemann DR, Magee JM, Boboila C, Calado DP, Gallagher MP, Portuguese AJ, Manis JP, Zhou X, Recher M, Rajewsky K, Notarangelo LD, Alt FW. Immature B cells preferentially switch to IgE with increased direct $\mathrm{S}$ to S recombination. Journal of Experimental Medicine. 2011; 208: 2733-2746.

52. Achatz G, Nitschke L, Lamers MC. Effect of Transmembrane and Cytoplasmic Domains of IgE on the IgE Response. Science. 1997; 276: 409-411.

53. Chen JB, Wu PC, Hung AFH, Chu CY, Tsai TF, Yu HM, Chang HY, Chang TW. Unique epitopes on $\mathrm{C}$ epsilon $\mathrm{mX}$ in IgE-B cell receptors are potentially applicable for targeting IgE-committed B cells. Journal of Immunology. 2010; 184: 1748-1756.

54. Brightbill HD, Jeet S, Lin Z, Yan D, Zhou M, Tan M, Nguyen A, Yeh S, Delarosa D, Leong SR, Wong T, Chen Y, Ultsch M, Luis E, Ramani SR, Jackman J et al. Antibodies specific for a segment of human membrane IgE deplete IgE-producing B cells in humanized mice. Journal of Clinical Investigation. 2010; 120: 2218-2229.

55. Wu PC, Chen JB, Kawamura S, Roos C, Merker S, Shih CC, Hsu BD, Lim C, Chang TW. The IgE gene in primates exhibits extraordinary evolutionary diversity Immunogenetics. 2012; 64: 279-287.

56. Karnowski A, Achatz-Straussberger G, Klockenbusch C, Achatz G, Lamers MC. Inefficient processing of mRNA for the membraneform of $\mathrm{IgE}$ is a genetic mechanism to limit recruitment of IgE-secreting cells. European Journal of Immunology. 2006; 36: 1917-1925.

57. Sitia R. Biosynthesis of membrane and secreted epsilonchains during lipopolysaccharide-induced differentiation of an IgE+ murine B-lymphoma. Molecular Immunology. 1985; 22: 1289-1296.

58. Erazo A, Kutchukhidze N, Leung M, Christ APG, Urban JF Jr, Curotto de Lafaille MA, Lafaille JJ. Unique maturation program of the IgE response in vivo. Immunity. 2007; 26: 191-203.

59. Batista FD, Anand S, Presani G, Efremov DG, Burrone OR. The Two Membrane Isoforms of Human IgE Assemble into Functionally Distinct B Cell Antigen Receptors. Journal of Experimental Medicine. 1996; 184: 2197-2206.

60. Poggianella M, Bestagno M, Burrone OR. The extracellular membrane-proximal domain of human membrane $\operatorname{IgE}$ controls apoptotic signaling of the B cell receptor in the mature B cell line A20. Journal of Immunol. 2006; 177: 3597-3605.

61. Oberndorfer I, Schmid D, Geisberger R, AchatzStraussberger G, Crameri R, Lamers M, Achatz G. HS1Associated Protein X-1 Interacts with Membrane-Bound IgE: Impact on Receptor-Mediated Internalization. Journal of Immunology. 2006; 177: 1139-1145.

62. Geisberger R, Prlic M, Achatz-Straussberger G,
Oberndorfer I, Luger E, Lamers M, Crameri R, Appenzeller U, Wienands J, Breitenbach M, Ferreira F, Achatz G. Phage Display Based Cloning of Proteins Interacting with the Cytoplasmic Tail of Membrane Immunoglobulins. Developmental Immunology. 2002; 9: 127-134.

63. Heine G, Dahten A, Hilt K, Ernst D, Milovanovic M, Hartmann B, Worm M Liver X receptors control IgE expression in B cells. Journal of Immunology. 2009; 182: 5276-5282.

64. Erazo A, Kutchukhidze N, Leung M, Christ APG, Urban JF Jr, Curotto de Lafaille MA, Lafaille JJ. Unique maturation program of the IgE response in vivo. Immunity. 2007; 26 : 191-203.

65. Xiong H, Dolpady J, Wabl M, Lafaille MAC, de Lafaille JJ. Sequential class switching is required for the generation of high affinity IgE antibodies. Journal of Experimental Medicine. 2012; 209: 353-364.

66. Talay O, Yan D, Brightbill HD, Straney EEM, Zhou M, Ladi E, Lee WP, Egen JG, Austin CD, Xu M, Wu LC. $\mathrm{IgE}+$ memory $\mathrm{B}$ cells and plasma cells generated through a germinal-center pathway. Nature Immunology. 2012; 13: 396-404.

67. Yang Z, Sullivan BM, Allen CDC. Fluorescent In vivo Detection Reveals that IgE+ B Cells Are Restrained by an Intrinsic Cell Fate Predisposition. Immunity. 2012; 36: 857-872.

68. Achatz-Straussberger G, Zaborsky N, Konigsberger S, Luger EO, Lamers M, Crameri R, Achatz G. Migration of antibody secreting cells towards CXCL12 depends on the isotype that forms the BCR. European Journal of Immunology. 2008; 38: 3167-3177.

69. Goodnow CC, Vinuesa CG, Randall KL, Mackay F, Brink R. Control systems and decision making for antibody production. Nature Immunology. 2010; 11: 681-688.

70. Pinaud E, Marquet M, Fiancette R, Péron S, Vincent-Fabert $\mathrm{C}$, Denizot Y, Cogné M. The IgH locus 3' regulatory region: pulling the strings from behind. Advances in Immunology. 2011; 110: 27-70.

71. Kim W, Kook S, Kim DJ, Teodorof C, Song WK. The $31-\mathrm{kDa}$ caspase-generated cleavage product of p130cas functions as a transcriptional repressor of E2A in apoptotic cells. Journal of Biological Chemistry. 2004; 279: 83338342.

72. Giambra V, Volpi S, Emelyanov AV, Pflugh D, Bothwell ALM, Norio P, Fan Y, Ju Z, Skoultchi AI, Hardy RR, Frezza D, Birshtein BK. Pax5 and linker histone H1 coordinate DNA methylation and histone modifications in the 3' regulatory region of the immunoglobulin heavy chain locus. Molecular and Cellular Biology. 2008; 28: 6123-6133.

73. Garrett FE, Emelyanov AV, Sepulveda MA, Flanagan P, Volpi S, Li F, Loukinov D, Eckhardt LA, Lobanenkov VV, Birshtein BK. Chromatin architecture near a potential 3' end of the igh locus involves modular regulation of histone 
modifications during B-Cell development and in vivo occupancy at CTCF sites. Molecular and Cellular Biology. 2005; 25: 1511-1525.

74. Dunnick WA, Collins JT, Shi J, Westfield G, Fontaine C, Hakimpour P, Papavasiliou FN. Switch recombination and somatic hypermutation are controlled by the heavy chain 3' enhancer region. Journal of Experimental Medicine. 2009; 206: 2613-2623.

75. Cogné M, Lansford R, Bottaro A, Zhang J, Gorman J, Young F, Cheng H L, Alt FW. A class switch control region at the 3' end of the immunoglobulin heavy chain locus. Cell. 1994; 77: 737-747.

76. Manis JP, van der Stoep N, Tian M, Ferrini R, Davidson L, Bottaro A, Alt FW. Class switching in B cells lacking 3' immunoglobulin heavy chain enhancers. Journal of Experimental Medicine. 1998; 188: 1421-1431.

77. Bébin AG, Carrion C, Marquet M, Cogné N, Lecardeur $\mathrm{S}$, Cogné $\mathrm{M}$, Pinaud E. In vivo redundant function of the 3' $\mathrm{IgH}$ regulatory element $\mathrm{HS} 3 \mathrm{~b}$ in the mouse. Journal of Immunology. 2010; 184: 3710-3717.

78. Pinaud E, Khamlichi AA, Le Morvan C, Drouet M, Nalesso V, Le Bert M, Cogné M. Localization of the 3' IgH locus elements that effect long-distance regulation of class switch recombination. Immunity. 2001; 15: 187-199.

79. Vincent-Fabert C, Fiancette R, Pinaud E, Truffinet V, Cogné N, Cogné M, Denizot Y. Genomic deletion of the whole IgH 3' regulatory region (hs3a hs 12 hs 3 b and hs4) dramatically affects class switch recombination and Ig secretion to all isotypes. Blood. 2010; 116: 1895-1898.

80. Wuerffel R, Wang L, Grigera F, Manis J, Selsing E, Perlot T, Alt FW, Cogne M, Pinaud E, Kenter AL. S-S synapsis during class switch recombination is promoted by distantly located transcriptional elements and activation-induced deaminase. Immunity. 2007; 27: 711-722.

81. Ju Z, Volpi SA, Hassan R, Martinez N, Giannini SL, Gold $\mathrm{T}$, Birshtein BK. Evidence for physical interaction between the immunoglobulin heavy chain variable region and the 3, regulatory region. Journal of Biological Chemistry. 2007; 282: 35169-35178.

82. Duan H, Xiang H, Ma L, Boxer LM. Functional long-range interactions of the IgH 3' enhancers with the bcl-2 promoter region in $\mathrm{t}(1418)$ lymphoma cells. Oncogene. 2008; 27: 6720-6728.

83. Gostissa M, Yan CT, Bianco JM, Cogné M, Pinaud E, Alt FW. Long-range oncogenic activation of Igh-c-myc translocations by the Igh 3' regulatory region. Nature. 2009; 462: 803-807.

84. Chauveau C, Cogné M. Palindromic structure of the $\operatorname{IgH}$ 3'locus control region. Nature Genetics. 1996; 14: 15-16.

85. Chauveau C, Pinaud E, Cogne M. Synergies between regulatory elements of the immunoglobulin heavy chain locus and its palindromic 3' locus control region. European Journal Immunology. 1998; 28: 3048-3056.

86. Sepulveda MA, Garrett FE, Price-Whelan A, Birshtein
BK. Comparative analysis of human and mouse 3' Igh regulatory regions identifies distinctive structural features. Molecular Immunology. 2005; 42: 605-615.

87. Pinaud E, Aupetit C, Chauveau C, Cogné M. Identification of a homolog of the $\mathrm{C}$ alpha 3 '/hs3 enhancer and of an allelic variant of the 3 ' $\mathrm{IgH} / \mathrm{hs} 12$ enhancer downstream of the human immunoglobulin alpha 1 gene. European Journal of Immunology. 1997; 27: 2981-2985.

88. Yamane A, Resch W, Kuo N, Kuchen S, Li Z, Sun H, Robbiani DF, McBride K, Nussenzweig MC, Casellas R. Deep-sequencing identification of the genomic targets of the cytidine deaminase AID and its cofactor RPA in B lymphocytes. Nature Immunology. 2011; 12: 62-69.

89. Rouaud P, Vincent-Fabert C, Saintamand A, Fiancette R, Marquet M, Robert I, Reina-San-Martin B, Pinaud E, Cogné M, Denizot Y. The IgH 3' regulatory region controls somatic hypermutation in germinal center B cells. Journal of Experimental Medicine. 2013; 210: 1501-1507.

90. Zhang Y, Meyer-Hermann M, George LA, Figge MT, Khan M, Goodall M, Young SP, Reynolds A, Falciani F, Waisman A, Notley CA, Ehrenstein MR, Kosco-Vilbois M, Toellner KM. Germinal center B cells govern their own fate via antibody feedback. Journal of Experimental Medicine. 2013; 210: 457-464.

91. Savelyeva N, Shipton M, Suchacki A, Babbage G, Stevenson FK. High-affinity memory B cells induced by conjugate vaccines against weak tumor antigens are vulnerable to nonconjugated antigen. Blood. 2011; 118 : 650-659.

92. Maruyama M, Lam KP, Rajewsky K. Memory B-cell persistence is independent of persisting immunizing antigen. Nature. 2000; 407: 636-642.

93. Pape KA, Taylor JJ, Maul RW, Gearhart PJ, Jenkins MK. Different B cell populations mediate early and late memory during an endogenous immune response. Science. 2011; 331: 1203-1207.

94. Dogan I, Bertocci B, Vilmont V, Delbos F, Mégret J, Storck S, Reynaud C-A, Weill J-C. Multiple layers of B cell memory with different effector functions. Nature Immunology. 2009; 10: 1292-1299.

95. Yates JL, Racine R, McBride KM, Winslow GM. T Cell-Dependent IgM Memory B Cells Generated during Bacterial Infection Are Required for IgG Responses to Antigen Challenge. Journal of Immunology. 2013; 191: 1240-1249.

96. Bessa J, Zabel F, Link A, Jegerlehner A, Hinton HJ, Schmitz N, Bauer M, Kündig TM, Saudan P, Bachmann MF. Low-affinity B cells transport viral particles from the lung to the spleen to initiate antibody responses. Proceedings of the National Academy of Sciences of the United States of America. 2012; 109: 20566-20571.

97. Link A, Zabel F, Schnetzler Y, Titz A, Brombacher F, Bachmann MF. Innate immunity mediates follicular transport of particulate but not soluble protein antigen. 
Journal of Immunology. 2012; 188: 3724-3733.

98. Weller S, Mamani-Matsuda M, Picard C, Cordier C, Lecoeuche D, Gauthier F, Weill JC, Reynaud CA. Somatic diversification in the absence of antigen-driven responses is the hallmark of the $\operatorname{IgM}+\operatorname{IgD}+\mathrm{CD} 27+\mathrm{B}$ cell repertoire in infants. Journal of Experimental Medicine. 2008; 205: 1331-1342.

99. Weller S, Bonnet M, Delagreverie H, Israel L, Chrabieh M, Maródi L, Rodriguez-Gallego C, Garty BZ, Roifman $\mathrm{C}$, Issekutz AC, Zitnik SE, Hoarau C, Camcioglu $\mathrm{Y}$, Vasconcelos J, Rodrigo C, Arkwright PD et al. IgM+IgD+CD27+ B cells are markedly reduced in IRAK-4MyD88- and TIRAP- but not UNC-93B-deficient patients. Blood. 2012; 120; 4992-5001.

100. Puga I, Cols M, Barra CM, He B, Cassis L, Gentile M, Comerma L, Chorny A, Shan M, Xu W, Magri G, Knowles DM, Tam W, Chiu A, Bussel JB, Serrano S, et al. B cell-helper neutrophils stimulate the diversification and production of immunoglobulin in the marginal zone of the spleen. Nature Immunology. 2012; 13: 170-180.

101. Liu M, Duke JL, Richter DJ, Vinuesa CG, Goodnow CC, Kleinstein SH, Schatz DG. Two levels of protection for the B cell genome during somatic hypermutation. Nature. 2008; 451: 841-845.

102. Staszewski O, Baker RE, Ucher AJ, Martier R, Stavnezer J, Guikema JEJ. Activation-induced cytidine deaminase induces reproducible DNA breaks at many non-Ig Loci in activated B cells. Molecular Cell. 2011; 41: 232-242.

103. Chiarle R, Zhang Y, Frock RL, Lewis SM, Molinie B, Ho YJ, Myers DR, Choi VW, Compagno M, Malkin DJ, Neuberg D, Monti S, Giallourakis CC, Gostissa M, Alt FW. Genome-wide translocation sequencing reveals mechanisms of chromosome breaks and rearrangements in B cells. Cell. 2011; 147: 107-119.

104. Gu X, Shivarov V, Strout MP. The role of activationinduced cytidine deaminase in lymphomagenesis. Current Opinion in Hematology. 2012; 19: 292-298.

105. Tsai AG, Lu H, Raghavan SC, Muschen M, Hsieh CL, Lieber MR. Human chromosomal translocations at $\mathrm{CpG}$ sites and a theoretical basis for their lineage and stage specificity. Cell. 2008; 135: 1130-1142.

106. Cui X, Lu Z, Kurosawa A, Klemm L, Bagshaw A, Tsai AG, Gemmell N, Muschen M, Adachi N, Hsieh CL, Lieber MR. Both CpG Methylation and AID are Required for the Fragility of the Human Bcl-2 Major Breakpoint Region: Implications for the Timing of the Breaks in the $\mathrm{t}(1418)$. Molecular and Cellular Biology. 201; 33: 947-57.

107. Barlow JH, Faryabi RB, Callén E, Wong N, Malhowski A, Chen HT, Gutierrez-Cruz G, Sun HW, McKinnon P, Wright G, Casellas R, Robbiani DF, Staudt L, Fernandez-Capetillo $\mathrm{O}$, Nussenzweig. A Identification of early replicating fragile sites that contribute to genome instability. Cell. 2013; 152: 620-632.

108. Coelho V, Krysov S, Ghaemmaghami AM, Emara M,
Potter KN, Johnson P, Packham G, Martinez-Pomares L, Stevenson FK. Glycosylation of surface Ig creates a functional bridge between human follicular lymphoma and microenvironmental lectins. Proceedings of the National Acadedmy of Sciences of the United States of America. 2010; 107: 18587-18592.

109. Ruminy P, Etancelin P, Couronné L, Parmentier F, Rainville V, Mareschal S, Bohers E, Burgot C, Cornic M, Bertrand P, Lenormand B, Picquenot J-M, Jardin F, Tilly H, Bastard C. The isotype of the BCR as a surrogate for the GCB and $\mathrm{ABC}$ molecular subtypes in diffuse large B-cell lymphoma. Leukemia. 2011; 25: 681-688.

110. Dühren-von Minden M, Übelhart R, Schneider D, Wossning T, Bach MP, Buchner M, Hofmann D, Surova E, Follo M, Köhler F, Wardemann H, Zirlik K, Veelken H, Jumaa H. Chronic lymphocytic leukaemia is driven by antigenindependent cell-autonomous signaling. Nature. 2012; 489: 309-312.

111. Davis RE, Ngo VN, Lenz G, Tolar P, Young RM, Romesser P B, Kohlhammer H, Lamy L, Zhao H, Yang Y, Xu W, Shaffer A L, Wright G, Xiao W, Powell J, Jiang JK et al. Chronic active B-cell-receptor signalling in diffuse large B-cell lymphoma. Nature. 2010 ; 463 : 88-92.

112. Gachard N, Parrens M, Soubeyran I, Petit B, Marfak A, Rizzo D, Devesa M, Delage-Corre M, Coste V, Laforêt MP, de Mascarel A, Merlio JP, Bouabdhalla K, Milpied N, Soubeyran P, Schmitt A et al. IGHV gene features and MYD88 L265P mutation separate the three marginal zone lymphoma entities and Waldenström macroglobulinemia/ lymphoplasmacytic lymphomas. Leukemia. 2013; 27: 183189. 